\title{
The Attribute Factors on the Successful Reading Lesson by ESL: A Literature Review
}

\author{
Philip Wilson John, Maslawati Mohamad* \\ Faculty of Education, Universiti Kebangsaan Malaysia, Bangi, Malaysia \\ Email: *maslawati@ukm.edu.my
}

How to cite this paper: John, P. W., \& Mohamad, M. (2020). The Attribute Factors on the Successful Reading Lesson by ESL: A Literature Review. Creative Education, 11, 2240-2248. https://doi.org/10.4236/ce.2020.1111164

Received: October 10, 2020

Accepted: November 10, 2020

Published: November 13, 2020

Copyright $\odot 2020$ by author(s) and Scientific Research Publishing Inc. This work is licensed under the Creative Commons Attribution International License (CC BY 4.0).

http://creativecommons.org/licenses/by/4.0/ (c) (i) Open Access

\begin{abstract}
Reading skill is one of the most important and crucial skills to attain in this modernization world. The low English proficiency among the English Second Language Learners (ESL) is a vital sign that they are indeed at risk at reading activity. This has made the ESL be in a difficult situation because they cannot cope with the learning aspect in reading. With appropriate approach and strategy, reading tasks can be more tolerant and permissive for the ESL. This literature review paper will unfold the basic strategies employed by learners of ESL to overcome the difficulties in reading which will lead them to successful classroom learning. The strategies used are heavily embedded with the spirit of collaboration among peers and also the application of the 21st learning classroom reading activities. If these approaches are fully employed, educators of ESL will see the tremendous change in students' attitude and their perception towards reading activity.
\end{abstract}

\section{Keywords}

$21^{\text {st }}$ Learning Classroom, Reading, English as a Second Language, English Reading Skills

\section{Introduction}

Reading is the essential life skill. It civilizes human beings. Through reading, it is not only enhancing knowledge, but also polishing thinking, improving awareness in socio economic perspective, politics and also environmental affairs (Jafre, Pour-Mohammadi, \& Jesmin, 2011). English as a Second Language (ESL) students regard reading as one of the most important skills to acquire. It helps them to understand the concept of English subject. Furthermore, since English is a mandatory subject to be learnt in school, ESL are struggling to excel in this subject. It is English language that will help them to survive in the open job market 
on globalized context. When they have finished school, college would be their last destination of the formal education for most individuals in Malaysia. Therefore, college institutions bear the responsibility of educating them on becoming established and steadfast learners. Unfortunately, many researchers observed the sad scenes and scenario in classrooms whereby they depended heavily on lectures output without considering reading printed materials and suggested reading lists by lecturers. This resulted in low quality of work in assignment and sometimes the contents were lifted mostly from the website. From many great minds of researchers, students can improve their learning by maximizing active content of their ideas and reading materials. They need to share insight on what they know in reading activity. Through collaboration, creative mind can be initiated. Bilbao et al. (2016) proved an important literary genre of reading situation whereby he suggested the golden interaction between learners and teachers is needed to form ideal classroom learning.

There have been a few studies conducted about mixed English language setting in Malaysia. The students of secondary school in suburban area in Kapit, Sarawak have been exerting themselves in ineffective strategies to understand English reading texts. This scenario is common in Malaysia because the system has emphasized more on the concentration of grammar teaching aspect as compared to other skills such as speaking, writing, listening and reading. As a result, the imbalance concentration of the learning skills in English has created serious repercussions. The students are in dire needs of scaffolding from their peers. What impedes their reading comprehension is due to lack of vocabulary level. The past studies have discussed about the major challenges of the ESL dealing with reading lessons and the attribute factors to the success of reading lesson by ESL. Therefore, this paper gives in depth concept of literature review on the factors contributing the success of reading skills among ESL.

\section{Literature Review}

\subsection{The Reading Performances among ESL in Malaysia}

The ESL have always been struggling with understanding text in reading. One of the factors could be contributed by the under exposure of the targeted language. The struggle always makes them lose focus and endurance in classroom. The teachers too contribute to this failure (Low, 2004, cited in Zakaria, 2005). The nature of learning has inevitably changed when students will no longer jotting down notes by using traditional way of handwritten. They instead will opt to choose laptops and tablet to take notes and browse useful website for their learning. Zhu et al. (2016) consider this breakthrough as another educational value and innovative teaching. Reading activities also can be made easy as vocabulary enhancement can be obtained by a single click away. A study proves that young adults will tend to download numerous applications that will help them in learning (The Demographics of Instagram and Snapchat Users, 2013). As they 
use the mobile application more often as compared to traditional learning method, classroom setting will be enhanced. Furthermore, the language used in the mobile application is usually English language.

In an international context, reading literacy can be measured by using PISA (Programme for International Students Assessment). PISA measures reading literacy as comprehending, working on written texts to reach certain goals and expanding one's knowledge for participation in society. As for Malaysia, the score for PISA was 415 in 2018 (Kannan, 2019). The performance for PISA assessment for Malaysia was not impressive back in 2012 and 2015. This implies that Malaysian students were not really into reading. Singapore and Philippine were in better ranking. It is further proven in Figure 1, as compared to Organization for Economic Co-operation and Development (OECD) average, only a small segment number of students who achieved greatly between the levels of proficiency of 5 and 6 in minimum one subject. Therefore, it can be concluded that Malaysian students achieved low score marks in all three assessments as compared to the average score. There were quite a number of discussions pertaining to Malaysian students' performance in PISA 2018. According to the report done by OECD in 2018, 54\% of students scored for Level 2 proficiency could only find the whole idea in a text of short length. At a lax percentage of students in Malaysia who were top achievers in reading (attained Level 5 or 6 in PISA), they could execute tasks in lengthy reading text and dealt with abstract concepts of ideas. Apart from that, they also could demonstrate distinct differences between fact and opinion.

The unimpressive performance in PISA for Malaysia has made it hard for the realization of Malaysian Education Plan 2013-2025 which is to achieve the best countries between Singapore and Philippine. While many factors that contributing to the underperformance of Malaysia's result on PISA, it is believed that family affairs and school institutional factor becomes one of the profound factors on students' result (Gundlach \& Wößmann, 2004). Furthermore, the way of system of education in Malaysia is differed as compared to the neighboring

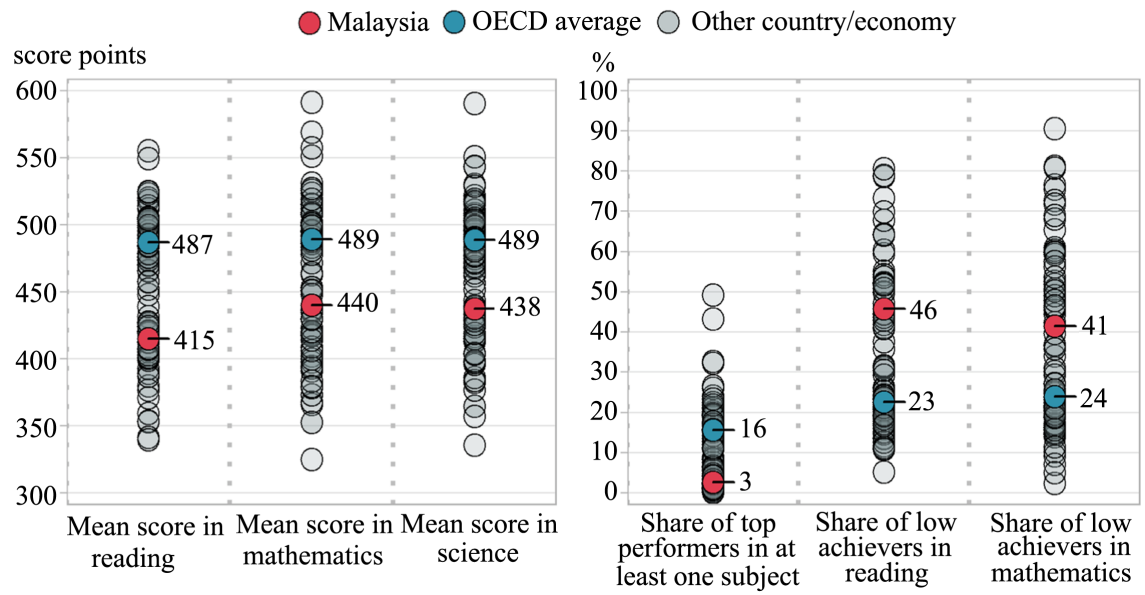

Figure 1. Source: OECD, PISA 2018 database. 
countries who did better in PISA. For example, Singapore lures top university leavers to enter teaching professions and this consequently produces fine quality teachers. On top of that, Singapore enforces strict requirements for those who wish to enter the teaching profession (Sclafani, 2008). It is only one-third of the top school leavers may be selected to enroll in teacher's colleges. From these comparisons, it is obvious that Malaysia is behind other countries which compromise the performance on PISA.

\subsection{The Issues in Reading by Malaysian ESL}

The studies on mobile usage indicate that youth tend to be more attached to mobile application than the older people. Mobile learning apps should be implemented in Malaysia to assist the educational process and to improve the learning process. Mobile learning is the process of learning that can be done anywhere at any time by using mobile technologies and internet (Masrom et al., 2016). Mobile learning is obviously not merely a combination of "mobile" and "learning". There is no proper or standard definition of mobile learning as many authors and researchers have given various definitions. Mobile learning also eliminates geographical boundaries. At the same time, it provides collaborative learning environment among groups, locally and globally.

ESL readers have the tendency to carry their own culture along and experience when reading takes place. Reports, contracts, blog writing are the example of the intensive readings. Intensive reading in ESL Malaysian students' context would be such a burden to them. It always frustrates them to read lengthy text. The content of the text could be difficult to understand thus can be slightly demotivating. These factors found to be influencing the reading problem. The study of intensive reading in ESL context has been explored in several studies. Kaur and Thiyagarajah (1999) have found that Malaysian students do not read much. Entertainment elements such as computer games, radio and television are preferred compared to readings. This scenario is consistent with that what has been reported by Malaysian National Library (2006). It was reported that the literacy rate decreased 1\% in 1996. A study done by Pandian and Balraj (2010) and Md Yasin et al. (2010) have discussed about the reluctancy of the reading habit by Malaysian students. The range of factors like the exposure to entertainment elements has influenced the process of developing the reading habits. Having said this, it makes no wonder that ESL students are struggling to fulfil task in reading.

\subsection{The Strategies in Reading by ESL}

Previous studies mostly defined extensive studies with different names and term. Even though each of the term comes with different terminologies, all of them share the same purpose which is the learners will read enormous amount of reading material in an atmosphere that promotes a never-ending reading habitual. Furthermore, it is understood that to achieve reading ability, one has to read extensively. Another way of achieving it was stated by Bruce Arne (1984). 
What is striking about what he postulated was in order to improve someone's knowledge is by living among its native speaker and read any targeted language extensively. Similar to Krashen Extensive Input Hypothesis, intensive reading is commonly used by Malaysian educator. In an intensive reading lesson, learners are exposed to a specific text and the elements usage of discourse system and linguistic aspects are intensified. Another perspective of this definition comes from Koay (2017) whereby intensive reading is done by dissecting the reading text word by word in detailed and meticulous manner. A precautionary measure has to be taken into account by regulating the text content and difficulties.

\subsection{Factors Contribute to Success in Reading}

For Malaysian ESL's context, it is hardly surprising that reading can be a very challenging yet interesting activity. Many strategies and techniques employed by teachers would make them become agitated in learning. With the immersion of context of learning into the concept of Education 4.0, learning has become something really unusual. Books, chalk and paper are likely to be retired from the hands of a teacher. Technology replaces it all. By infusing technological aspect into reading lesson has made the situation more appealing. Reading text has become more graphic and interactive. Whenever a teacher brings materials that will work well with technology, it is a cause for a celebration in the class. The integration of ICT especially gamification and artificial intelligence is what the young learners prefer in class (Fatin et al. 2018, Jamila \& Maslawati, 2017). Hashim et al. (2019) also has shown an agreement on the usage of gamification which is claimed to be very useful in education. There are quite a number of skills that can be improved through technology infusion and one of it is certainly reading. The ESL are found to be very motivated completing task in reading because of the instant rewards that they have gained at the end of the task. The result and feedback of the small task can be received almost instantaneously which enhances the speed and process of self-reflection at the end of the lesson. The self-exploratory method embedded in the concept of technological learning has somehow can increase students' level of vocabulary because they will encounter new terminologies. This strategy produced results which corroborate the findings of a great deal of the previous work in Ramamuruthy and Rao (2015) whereby a study conducted on 70 ESL students in local university in Malaysia revealed that technology permits them to receive input in learning such as creative thinking and collaboration to a certain level. Therefore, one of the success criteria of reading is through the incorporation of technology in reading lesson.

The impact of prosodic reading is understudied, particularly in the setting of students from suburban. Low proficiency ESL students often resort this approach when dealing with certain type of discourses especially reading. Prosodic reading is a dynamic fluctuation of rhythm, sound and intonation used in reading activity. Sometimes, it is done by an individual student or as a whole class performance. It is useful for lower proficiency class to intermediate profi- 
ciency class when they are pivoting their attention to semantic information. Their focus will be compounded when every difficulty is notified during reading. There are quite number of ESL students who choose to use their fingers to point the individual word that is being read. This also helps them to maintain the pace of reading so they will not skid from the rhythm. For prosodic reading experiences, teachers can choose certain reading materials which are appropriate. The text is characterized in intense rhythmical quality and intensified stress on voice. With a text that has an intense rhythmical voice in passages or the whole plays, it is intended to be played orally by the whole class. To ensure the voices convey meaning to their peers, the poetry is played orally. When the teacher has set up the reading activity with heavy infusion of reading-out-loud materials, the auditory learners will benefit much from it. They will be able to maximize their potential to process information and vocabulary output. This amazing way of doing reading activity sometimes can be converted to comprehension exercise and writing drills. The focus on conveying meaning through vocal must be engaged in scripts performing and rehearsing. In accordance with the positive outcome from this strategy, one previous study conducted by Sinambela (2017) has implied the effectiveness of prosodic reading among ESL. In her study, 10 participants of undergraduate students from a language center in Medan, Indonesia, took a reading aloud assignment and the findings were quite encouraging. The result showed a true prevalence of prosody as a tool of an attested sign to determine students' reading comprehension performance and their fluency in reading. On the same note, those who did not employ prosodic reading during the test were not able to comprehend the text given. Therefore, this concept draws a very interesting approach for ESL students to excel in their reading activity.

When reading is assisted by another knowledgeable and fluent reader, the reading will eventually become meaningful (Rasinski et al., 2011). Assisted reading is another fruitful way by ESL students to develop their reading skills in classroom. To perform this activity, it can be done with a big group of other readers (choral reading) and assisted reading with a pre-recorded track of the same text or reading with a partner (paired reading). ESL students mostly will resort to choose a strategy of reading by grabbing a partner and read together. When choral reading is often associated with primary school students, research has shown that advanced institutions learners have also practiced the same method (Paige \& Magpuri-Lavell, 2011). The whole class will read the text aloud along with their teacher. This creates some sort of "tent of anonymity" (Paige \& Magpuri-Lavell, 2011). Many ESL prefer to read this way as it envelopes the potential feeling of being ashamed or laughed by other peers. Surprisingly, other older ESL students who try so hard with fluency have shown tremendous improvement in their reading fluency because this situation invigorates their mood to read. The substantial growth and quality in reading fluency have promised a better and flexible way that can go beyond the context of fairly directive way of 
doing exercise in Malaysian syllabus context. This is because, Nambiar (2007) rises a note of caution that the dominant context of learning reading in Malaysia is based on exam content orientation whereby reading is just having to read text for the sake of answering comprehension questions with presumably a general multiple-choice type of questions. Previous research conducted by Kodan \& Akyol (2018) has indicated potential associations between assisted reading and students' performance in reading. Kodan \& Kayol (2018) conducted on a study group comprised of six fourth grade primary school students from a public school in Bayburt province of Turkey. Pre-assessment and post-assessment test were applied and there was a significant difference in the reading comprehension marks in the informative text. This substantial result proved that assisted reading approach was in fact have positive effects on the comprehension skills of the weak readers.

\section{Conclusion and Implications}

In this context of existing literature about reading and its challenges in ESL classroom, it can be concluded that they are a few strategies that can be employed by the students to excel in reading skills. The success in reading can be outlined in several ways such as immersing in technological features of reading materials, collaborating in prosodic reading and involving in an assisted reading activity. The past few studies have really emphasized on the autonomy power given entirely to students to manage their own learning. Teacher has to become their facilitator and guidance in order for the lesson to run smoothly. This scenario is really hooked to the concept of 21st learning century classroom whereby the infusion of technological aspect like Instagram and Facebook becomes one of the centers of attention to promote learning aspect. Apart from the educator's awareness, the needs of learning are very important because it will determine their effective tool in reading approach. The theoretical implications of these literature may be applicable to the Malaysia Ministry of Education in outlining their future philosophical approach in redesigning and polishing the concept of effective learning strategies for ESL particularly.

\section{Conflicts of Interest}

The authors declare no conflicts of interest regarding the publication of this paper.

\section{References}

(2013). The Demographics of Instagram and Snapchat Users. https://www.marketingcharts.com/digital-37745

Bilbao, M., Donguilla, C., \& Vasay, M. (2016). Level of Reading Comprehension of the Education Students. International Journal of Liberal Arts, Education, Social Sciences and Philosophical Studies, 4, 342-353. http://ejournals.ph/form/cite.php?id=13762

Bruce Arne, S. (1984). Teaching Reading Skills in a Foreign Language. System, 12, 188-190. https://doi.org/10.1016/0346-251X(84)90031-9 
Fatin Kamilia, M. A., Natasha, Z. Z., Maslawati, M., \& Melor, M. Y. (2018). Anxiety and Kahoot Performance among Tertiary Level Students. International Journal of Engineering and Technology, 7, 26-32.

Gundlach, E., \& Wößmann, L. (2004). Family Background, Schooling Resources, and Institutional Features: What Determines Student Performance in East Asian Countries? Kiel: Kiel Institute for the World Economy.

Hashim, H., Rafiq, K. R. M., \& Md Yunus, M. (2019). Improving ESL Learners' Grammar with Gamified-Learning. Arab World English Journal, 5, 41-50. https://doi.org/10.24093/awej/call5.4

Jafre, M. Z. A., Pour-Mohammadi, M., \& Jesmin, A. (2011). A Survey of Online Reading Habits of Rural Secondary School Students in Malaysia. International Journal of Linguistics, 3, 1-18.

Kannan, H. V. (2019). Malaysia's PISA Ranking Improves. New Straits Times, 3rd December 2019.

Kaur, S., \& Thiyagarajah, R. (1999). The English Reading Habits of ELLS Students in University Science Malaysia. Proceedings of the Sixth International Literacy and Education Research Network Conference on Learning, Malaysia, 27 September 1999.

Koay, J. (2017). What Is Intensive Reading? Independent Researcher and a Research \& Development Consultant at EduMaxi. Wellington: Victoria University of Wellington, School of Linguistics and Applied Language.

https://www.researchgate.net/post/what is reading skill and its significance

Kodan, H., \& Akyol, H. (2018). Effects of Choral, Repeated and Assisted Reading Strategies on Reading and Reading Comprehension Skills of Poor Readers. Education \& Science, 43, 159-179. https://doi.org/10.15390/EB.2018.7385

Malaysian National Library (2006). The Reading Profile of Malaysians 2006. Kuala Lumpur: The Malaysian National Library.

Masrom, M., Nadzari, A. S., \& Zakaria, S. A. (2016). Implementation of Mobile Learning Apps in Malaysia Higher Education Institutions. E-Proceeding of the 4th Global Summit on Education, Malaysia, 15March 2016, 268-276.

Md Yasin, A. Y., Wan Mohd Shaupil, W. M. H., Mukhtar, A., Ghani, N., \& Farawaheeda, R. (2010). The English Proficiency of Civil Engineering Students at a Malaysian Polytechnic. Asian Social Science, 6, 161. https://doi.org/10.5539/ass.v6n6p161

Nambiar, R. M. K. (2007). Enhancing Academic Literacy among Tertiary Learners: A Malaysian Experience. 3L: The Southeast Asian Journal of English Language Studies, 13, 77-94.

Paige, D. D., \& Magpuri-Lavell, T. (2011). Unpacking Adolescent Literacy Skills in a High-Poverty, Urban High School. In T. Morrison, L. Martin, M. Boggs, \& S. Szabo (Eds.), Association of Literacy Educators and Researchers Yearbook: Literacy Promises (Vol. 33, pp. 219-236). Commerce, TX: Association of Literacy Educators and Researchers.

Pandian, A., \& Balraj, S. (2010). Driving the Agenda of Learning by Design in Science Literacy in Malaysia. E-Learning and Digital Media, 7, 301-316. https://doi.org/10.2304/elea.2010.7.3.301

Ramamuruthy, V., \& Rao, S. (2015). Smartphones Promote Autonomous Learning in ESL Classrooms. Malaysian Online Journal of Educational Technology, 3, 23-35.

Rasinski, T. V., Reutzel, C. R., Chard, D., \& Linan-Thompson, S. (2011). Reading Fluency. In M. L. Kamil, P. D. Pearson, E. B. Moje, \& P. P. Afflerbach (Eds.), Handbook of Reading Research (Vol. IV, pp. 286-319). New York: Routledge.

Sclafani, S. (2008). Rethinking Human Capital in Education: Singapore as a Model for 
Teacher Development. Washington DC: Aspen Institute.

Sinambela, S. E. (2017). Prosody as A tool for Assessing Reading Fluency of Adult ESL Students. Advances in Language and Literary Studies, 8, 83-87. https://doi.org/10.7575/aiac.alls.v.8n.6p.83

Zakaria, Z. (2005). Dictionary as Tool in Vocabulary Acquisition for Rural Students. Unpublished Master's Dissertation, Pulau Pinang: Universiti Sains Malaysia.

Zhu, Z., Yu, M.-H., \& Riezebos, P. (2016). A Research Framework of Smart Education. Smart Learning Environments, 3, 4. https://doi.org/10.1186/s40561-016-0026-2 